\title{
PEMANFAATAN BIG DATA DAN PERLINDUNGAN PRIVASI KONSUMEN DI ERA EKONOMI DIGITAL
}

\author{
Agung Pujianto ${ }^{1)}$, Awin Mulyati ${ }^{2)}$, Rachmawati Novaria ${ }^{3)}$ \\ Program Studi Administrasi Bisnis Untag Surabaya \\ Email : agung@untag-sby.ac.id
}

\begin{tabular}{ll}
\hline ARTICLE INFO & ABSTRACT \\
\hline Keywords: & Kehadiran internet telah merevolusi cara kerja dunia ini dengan begitu cepatnya. Dunia \\
Digital Ekonomy, & kini memasuki sebuah era digitalisasi yakni sebuah era yang menekankan pada pola \\
Big Data, & digital economy dan big data. Big Data melibatkan proses pembuatan data, \\
Koseptual-Tradisional, & penyimpanan, penggalian informasi, dan analisis yang menonjol dalam hal volume, \\
Perlindungan Konsumen. & velocity, dan variety. Bagi kalangan industri atau praktisi, big data telah membuka \\
& peluang untuk menetapkan strategi bisnis. Penelitian ini ingin melihat sejauh mana \\
& teknologi Big Data sudah dimanfaatkan di Indonesia baik lembaga pemerintah maupun \\
& swasta, apa tantangan dalam penerapanya, serta bagaimana dampak penerapan Big \\
& Data terhadap privasi konsumen. Metode riset menggunakan kajian literatur dengan \\
& pendekatan konseptual-tradisional. Data primer adalah jurnal-jurnal yang sudah \\
& dipublikasikan terkait dengan topik yang penulis kaji dan beberapa pemberitaan yang \\
& bersumber dari media sosial. Kesimpulan pemanfaatan Big Data di Indonesia sudah \\
& mulai tumbuh baik di sektor bisnis maupun di sektor publik. Tantangan yang ada saat \\
ini lebih pada bagaimana perusahaan mengoptimalkan data yang dimiliki, dan terkai & dengan pelanggaran privasi perlu adanya kepastian hukum dan pemahaman terkait \\
& etika dalam penggunaan teknologi informasi.
\end{tabular}

\section{INTRODUCTION}

Perkembangan teknologi semakin pesat tersebar luas dan mempengaruhi segenap bidang kehidupan. Teknologi sudah menjadi bagian tidak terpisahkan dalam kehidupan manusia sehari - hari. Hal ini dapat dibuktikan dengan banyaknya inovasi-inovasi yang telah dibuat di dunia ini. Mulai dari inovasi yang sederhana, hingga inovasi yang menghebohkan dunia. Dulu internet dianggap sebagai sesuatu yang "wah" ,namun sekarang bisa kita saksikan sendiri faktanya ,internet telah menjadi sesuatu yang umum bagi banyak orang, hampir semua orang berinteraksi secara intensif dengan individu lain secara maya melalui berbagai jejaring sosial.

Indonesia tentunya memiliki potensi yang besar dalam pengembangan teknologi berbasis internet. Ini artinya arus globalisasi sudah tidak terbendung untuk masuk ke Indonesia. Disertai dengan perkembangan teknologi yang semakin canggih. 
Berdasarkan data populasi penduduk Indonesia saat ini mencapai 262 juta orang. Lebih dari 50 persen atau sekitar 143 juta orang telah terhubung jaringan internet sepanjang 2017, setidaknya begitu menurut laporan teranyar Asosiasi Penyelenggara Jasa Internet Indonesia ( APJII). Angka ini menempatkan Indonesia pada urutan ke-5 sebagai negara dengan jumlah pengguna internet terbesar di dunia setelah China, India, Amerika Serikat, dan Brasil. Tingkat penetrasi internet di Indonesia hingga Maret 2017 mencapai $50,4 \%$, wajar bila pertumbuhan Internet di Indonesia begitu besar meningkat drastis dari tahun 2016 yang tercatat $34,1 \%$.

Kehadiran internet beberapa dekade yang lalu benar-benar telah merevolusi cara kerja dunia ini dengan begitu cepatnya. Informasi mengalir begitu cepatnya bahkan secara real time. Kecepatan informasi membuat waktu seperti terpangkas, dunia ini seperti mengalami lompatan waktu. Pada satu sisi perkembangan teknologi yang begitu mengagumkan dan membawa manfaat yang luar biasa bagi kemajuan peradaban manusia. Jenis-jenis pekerjaan yang sebelumnya menuntut fisik yang cukup besar, kini relatif sudah bisa digantikan oleh perangkat mesin-mesin otomatis, seolah kehadiran teknologi sudah mampu menggeser posisi kemampuan otak manusia dalam berbagai ilmu dan aktivitas manusia. Kemajuan teknologi sekarang benar-benar telah diakui dan dirasakan memberikan banyak kmudahan dan kenyamanan bagi umat manusia.

Thomas L Friedman menggunakan istilah globalisasi 3.0 untuk menyebut era internet ini, yang di dalamnya kehidupan manusia diwarnai penggunaan teknologi digital. Pada masa ini dunia menyusut dari ukuran kecil menjadi ukuran sangat kecil. Aktor utama pada masa ini adalah individu-individu dan kelompok-kelompok kecil terkonvergensi dengan internet dan saling terhubung di dunia digital. Pada era ini setiap individu bisa dengan mudah memperoleh informasi sekaligus juga dapat menjadi narasumber melalui jaringan internet.

Dunia kini memasuki sebuah era digitalisasi yang disebut era revolusi industri 4.0, yakni sebuah era yang menekankan pada pola digital economy. "Everything is digital"adalah istilah yang tepat di dekade abad ini. Sebuah era dimana ketersediaan data sosial yang terekam secara digital semakin berlimpah. Lautan data ini mengarah pada satu terminologi Big Data. Bagi kalangan industri atau praktisi, big data telah membuka peluang untuk menetapkan strategi bisnis serta inovasi dalam hal memproses, menganalisis dan menyimpan data dengan volume serta tingkat votalitas yang tinggi serta cepat dan efektif. Oleh karenanya, pihak yang mampu mengolah dan memanfaatkan data-data yang tersedia dalam volume besar, keragaman vareatif, kompleksitas tinggi dan kecepatan penambahan data yang tinggi, dapat mengambil keuntungan yang besar.

Berlimpahnya data secara kuantitas serta beragam, menuntut sebuah mekanisme analisis data secara menyeluruh, atau setidaknya mewakili populasi big data tersebut, Meski aplikasi untuk menganalisis big data banyak tersedia di internet, tetapi akses terhadap big data itu sendiri sangat terbatas. 
Penelitian yang memanfaatkan Big Data masih belum populer di Indonesia khususnya para peneliti ilmu sosial. Disamping karena keterbatasan piranti lunak serta keterbatasan akses terhadap Big Data. Untuk itu pertanyaan penelitian yang bisa diajukan sejauh mana teknologi Big Data sudah dimanfaatkan di Indonesia baik lembaga pemerintah maupun swasta, apa tantangan dalam penerapanya, serta bagaimana dampak penerapan Big Data terhadap privasi konsumen.

\section{LITERATUR REVIEW}

Big Data Secara Konseptual

Big Data bukanlah sebuah teknologi, teknik, maupun inisiatif yang berdiri sendiri. Big Data adalah suatu trend yang mencakup area yang luas dalam dunia bisnis dan teknologi. Big Data menunjuk pada teknologi dan inisiatif yang melibatkan data yang begitu beragam, cepat berubah, atau berukuran super besar sehingga terlalu sulit bagi teknologi, keahlian, maupun infrastruktur konvensional untuk dapat menanganinya secara efektif. Dengan kata lain, Big Data memiliki ukuran (volume), kecepatan (velocity), atau ragam (variety) yang terlalu ekstrim untuk dikelola dengan teknik konvensional. Big Data melibatkan proses pembuatan data, penyimpanan, penggalian informasi, dan analisis yang menonjol dalam hal volume, velocity, dan variety.(Kompasiana:januari 2016).

Menurut (Eaton, Dirk, Tom, George, \& Paul) Big Data merupakan istilah yang berlaku untuk informasi yang tidak dapat diproses atau dianalisis menggunakan alat tradisional.

Menurut (Dumbill, 2012), Big Data adalah data yang melebihi proses kapasitas dari kovensi sistem database yang ada. Data terlalu besar dan terlalu cepat atau tidak sesuai dengan struktur arsitektur database yang ada. Untuk mendapatkan nilai dari data, maka harus memilih jalan altenatif untuk memprosesnya.

Big data is high-volume, high-velocity and/or high-variety information assets that demand cost-effective, innovative forms of information processing that enable enhanced insight, decision making, and process automation. (Gartner's )

Secara umum big data dapat diartikan sebagai sebuah kumpulan data yang berukuran sangat besar (volume), sangat cepat berubah/bertumbuh (velocity), hadir dalam beragam bentuk/format (variety). Serta memiliki nilai tertentu (value). Dengan catatan jika berasal dari sumber yang akurat (veracity). [2].

\section{Teknologi Big Data}

Teknologi Big Data adalah teknologi yang memungkinkan proses pengolahan data dengan empat ciri diatas. Sebelum munculnya teknologi ini, pengolahan data hampir selalu dilakukan oleh programmer dan sangat memakan waktu. 
Proses ini bertujuan agar setiap bisnis, organisasi ataupun individu yang mampu mengolah data tersebut bisa mendapatkan informasi lebih mendalam (insights) yang akan memicu pengambilan keputusan (decision making) dan tindakan (action) bisnis yang mengandalkan insights tersebut, bukan berdasarkan insting semata.

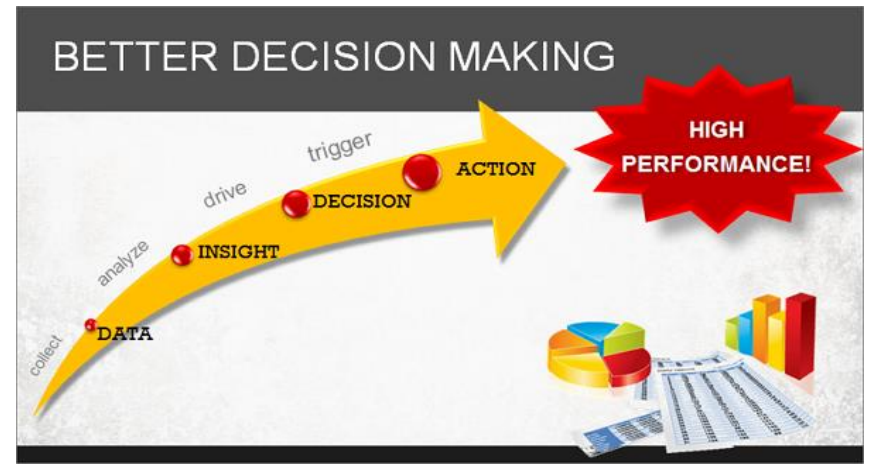

Dari Data Menjadi Tindakan untuk Menaikkan Kinerja Perusahaan

\section{METODE PENELITIAN}

Penelitian ini merupakan kajian literatur dengan pendekatan konseptual-tradisional. Kajian literatur adalah sebuah produk tulisan yang mengupas sebuah topik atau hasil penelitian yang telah dipublikasikan, tanpa ada gambaran metode ilmiah(Jesson et al.,2011:10) Setidaknya ada dua pendekatan dalam menulis kajian literatur: pendekatan tradisional dan pendekatan sistematik (p.14). Pendekatan tradisional di dalam kajian literatur memiliki beberapa pendekatan seperti critical approach, a conceptual review, a state-of-art review, an expert review, a scoping review(p.15). Artikel ini menggunakan pendekatan konseptual-tradisional di mana mensitesiskan pengetahuan atau hasil penelitian di bidang atau topik tertentu, yang dalam ini adalah Big Data, dengan tujuan untuk memberikan pemahaman mendalam tentang topik tersebut. [1]

Data primer dalam kajian literatur adalah jurnal-jurnal yang terkait dengan topik yang penulis kaji dan beberapa pemberitaan yang bersumber dari media sosial.

\section{Pembahasan}

\section{Pemanfaatan Big Data di Indonesia}

Data dan bisnis seolah menjadi paket lengkap keduanya tidak bisa dipisahkan. Sebagai bisnis yang berjalan di era teknologi tentu data lengkap dengan analisisnya merupakan bagian terpenting yang dapat menopang arah kebijakan dalam menjalankan bisnis. Analisis data yang lengkap bukan lagi hanya menjadi kompetensi yang penting bagi organisasi perusahaan akan tetapi sebagai penentu penguasaan pasar dan dijadikan dasar acuan ke mana bisnis akan berjalan dan dikembangkan. 
Beberapa manfaat Big Data yang sudah dirasakan khususnya bagi dunia usaha diantaranya untuk mengetahui respon masyarakat terhadap produk-produk yang dikeluarkan melalui analisis sentimen di media sosial; membantu perusahaan mengambil keputusan secara lebih tepat dan akurat berdasarkan data; membantu citra perusahaan di mata pelanggan; untuk perencanaan usaha dengan mengetahui perilaku pelanggan, seperti pada perusahaan telekomunikasi dan perbankan;serta mengetahui trend pasar dan keinginan konsumen. Teknologi Big Data membantu perusahaan dapat mengenali perilaku pelanggan melalui struk transaksi belanja. Data dari tiap struk transaksi tentunya berisi kombinasi produk-produk yang dibeli, jumlah dan harganya. Seluruh data transaksi tersebut kemudian dicari pola belanja untuk menjawab pertanyaan: kombinasi dua atau tiga produk apa saja yang paling sering dibeli oleh konsumen. Dari hasil informasi tersebut ada beberapa tindakan menarik yang dapat dilakukan, diantaranya: menyusun rak belanja agar dua atau tiga produk tersebut berdekatan sehingga mudah dijangkau oleh konsumen dan dapat diputuskan untuk dibeli dengan cepat. Kemudian bisa membuat paket promosi dimana kombinasi produk-produk tersebut dijual lebih murah.

Tindakan ini terbukti dapat meningkatkan penjualan secara signifikan dan mengurangi masalah inventori / stok.

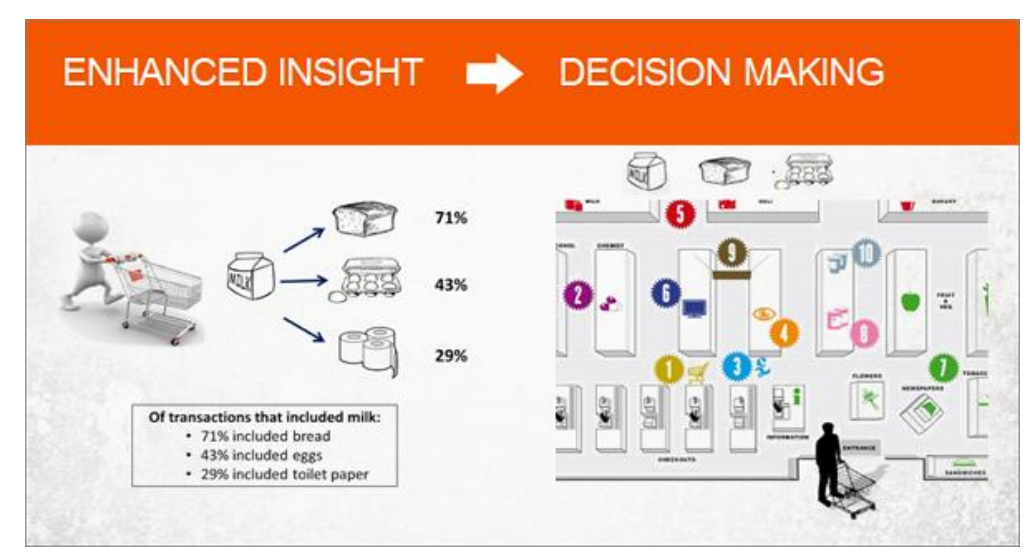

Shopping Basket Analysis

Awalnya, permasalahan ini kelihatan mudah dan bisa dipecahkan dengan program spreadsheet seperti Excel. Namun, tahukah Anda jika Anda memiliki 1000 item SKU (produk) dari seluruh struk transaksi maka Anda sudah memiliki 999,000 kombinasi dua produk yang perlu dicek kembali ke data-data transaksi.

Berapa lama waktu yang anda perlukan dengan menggunakan spreadheet? Dua minggu? Sebulan?. Namun, jika digabungkan dengan penggunaan teknologi data mining mungkin hanya memerlukan waktu beberapa detik atau mungkin paling lama 1 jam. (www.apaitubigdata.com; diakses tgl 2/5/2018).

Semakin banyak data yang dapat dikumpulkan dari pelanggan melalui berbagai parameter, seperti misalnya program loyalitas, pola kunjungan pencarian, histori pembelian, akan memperkaya para pelaku bisnis mampu menentukan pola perilaku yang berguna untuk meramalkankompleksitas lingkungan pasar mereka, dan dengan demikian mampu bertindak dan memutuskan langkah-langkah pencegahan. Menjaga konsumen 
agar tetap loyal sebelum mereka beralih ke kompetitor lain. Pada era informasi yang berlebihan, sangat penting untuk memilih secar hati-hati informasi yang akan ditransmisikan ke pelanggan potensial. [3]

Sejauh ini selain dua bidang Telekomunikasi dan Perbankan bidang usaha pengguna utama Big Data di Indonesia yaitu produksen barang-barang konsumsi ringan dan murah serta Perusahaan Asuransi.

Selain bermanfaat untuk analisis bisnis, teknologi Big Data juga dapat dimanfaatkan secara luas di pemerintahan. Beberapa peluang pemanfaatan Big Data di sektor publik antara lain untuk mendapatkan feedback dan respon masyarakat dari sistem informasi layanan pemerintah maupun dari media sosial, sebagai dasar penyususnan kebijakan dan perbaikan pelayanan publik; menemukan solusi atas permasalahan yang ada berdasarkan data yang ada, contohnya dengan menganalisis informasi cuaca dan tingkat kesuburan tanah, pemerintah dapat menetapkan atau menghimbau jenis varietas tanaman yang ditanam oleh perani pada daerah dan waktu tertentu. [4]

Dibidang Tambang, teknologi Big Data juga dapat mengenali sumber daya mineral dan energi baru. Teknologi Big Data selain memampukan berjalannya pemerintahan dengan baik, juga memampukan pemerintah menjawab persoalan-persoalan kabupaten dengan cepat dan tepat - dari masalah banjir, panen, hingga kemiskinan. Sebagai Contoh Kabupaten Bojonegoro salah satu kabupaten di Jawa Timur ini memasuki tahap Big Data dalam program Open Government Partnership. Pemerintah terbuka di sini tak lain adalah pemerintah yang transparan, membuka akses informasi seluas-luasnya kepada rakyat, membuka ruang keterlibatan warga untuk mengontrol jalannya pemerintahan. Bojonegoro pun terpilih sebagai satu-satunya wakil Indonesia dalam Pilot Project Open Government. Ini merupakan gerakan pemerintahan terbuka dalam mempromosikan dan memperkuat pengelolaan birokrasi yang terbuka, partisipatif, inovatif, dan responsif. Dalam program ini, Bojonegoro berarti sejajar dengan kota lain di dunia, seperti Seoul, Paris, Madrid, Buenos Aires, maupun Sao Paulo.

Big Data dan model Bisnis

Menurut studi konsumen digital generasi ke-3 hampir 50\% konsumen mengatakan bahwa mereka telah melakukan kegiatan yang terkait dengan pelanja lewat ponsel mereka dalam tiga bulan terakhir. Konsumen menyatakan mereka menggunakan teknologi digital untuk riset, penjelajahan dan pembelian semua dilakukan di satu situs web [5]. Keberadaan model bisnis seperti perdagangan secara elektronik (eCommerce) dan layanan keuangan berbasis teknologi (Financi, al Technology/Fintech) seperti ini telah mengubah praktik bisnis yang dulu lazim dilakukan. Fenomena ini membuat startup-startup baru seperti penyedia jasa angkutan online melesat naik hingga skala internasional hanya dalam hitungan tahun, bukan decade, dan perusahaan-perusahaan ini memiliki akses terhadap pengukuran kesuksesan real-time yang lebih baik dibanding sebelumnya. Alasan mengapa banyak perusahaan taksi dapat dikalahkan oleh perusahaan angkutan online, adalah karena perusahaan taksi masih mengandalkan contact center dan telepon untuk memesannya yang mana kurang efektif dan praktis bagi konsumen dibanding sistem point dan klik seperti Agung Pujianto,et.al.(Pemanfaatan Big Data Dan Perlindungan Privasi Konsumen Di Era Ekonomi Digital) 
yang diterapkan perusahaan angkutan online. Perusahaan angkutan online maju dengan pesat seperti sekarang adalah kemampuan mereka untuk mengelola big data daripada siapapun di pasar transportasi. Mereka dapat melacak kebiasaan pengguna mereka dengan kecepatan yang tidak dapat diikuti oleh kompetitornya saat ini.

Kemajuan teknologi telah mengubah cara seseorang bersikap. Konsumen menjadi sadar akan perdagangan elektronik dan memunculkan kekawatiran disisi lain. Hasil riset 35\% responden percaya bahwa lebih banyak informasi akan mengurangi rasa kekawatiran. Sebanyak 57\% responden masih menghindari pembelian barang mewah.[6]

Di tengah masa transisi ini ternyata muncul kenyataan pahit, salah satu raksasa ritel harus rela gulung tikar karena termakan zaman. Perusahaan-perusahaan ritel satu per satu tumbang yang dimulai dengan penutupan gerai Matahari Department Store sekitar September 2017. Tak berselang lama, usaha serupa seperti Ramayana Department Store, Lotus, menyusul Debenhams memilih tutup. Di pihak lain Blibli.com sebuah market place mampu melihat kecenderungan pelanggan mereka pada hari-hari tertentu. Promo-promo tematik yang spesial diluncurkan (Monday's Mom Day; Rabu Cantik, Kamis Ganteng dan FWD), penyediaan stok untuk promo spesial serta new product launching, serta melakukan forecasting lebih tepat sasaran, semua adalah hasil dari pemanfaatan big data. Ini tentu sebuah keputusan strategis yang terkait dengan persoalan strategi bisnis apakah tetap mau bertahan dengan model konvensional dengan berbagai konsekuensinya atau mengadopsi bisnis model baru.

Semakin banyak data yang dapat dikumpulkan dari pelanggan melalui berbagai parameter, seperti misalnya program loyalitas, pola kunjungan pencarian, histori pembelian, akan memperkaya para pemain ecommerce untuk memproses informasi ini guna melaksanakan pemetaan atau segmentasi pelanggan dalam rangka menciptakan layanan dan konten - konten promosi yang lebih terpersonalisasi. (Michael Erlangga). Big data membuat para pelaku bisnis mampu menentukan pola perilaku yang berguna untuk meramalkankompleksitas lingkungan pasar mereka, dan dengan demikian mampu bertindak dan memutuskan langkah-langkah pencegahan. Menjaga konsumen agar tetap loyal sebelum mereka beralih ke kompetitor lain.

\section{Tantangan penerapan Big data}

Jumlah data tumbuh sangat cepat. Pada 2020, diproyeksikan tiap manusia di muka bumi akan memproduksi 1,7 megabyte data setiap detiknya,Dengan demikian, Big Data bukan lah sesuatu yang dapat dipilih oleh korporasi, tapi sudah menjadi suatu kewajiban. Jika menentang, maka tinggal tunggu waktu untuk diganyang

Dewasa ini, big data technology memang sedang terjadi di Indonesia, walaupun belum menjadi sebesar $e$ commerce. Dalam dua tahun terakhir pemanfaatan big data sudah mencapai 90 persen di berbagai belahan dunia. Hanya saja di Indonesia pemanfaatan dan aplikasinya masih minim pada berbagai macam aspek 
kehidupan masyarakat. Saat ini data masih didominasi oleh konsumen internet. Namun, diharapkan ke depannya akan segera bergerak ke industrial consumer serta akan diikuti dengan pemerintahaan berbasis internet.

Dari hasil riset diperoleh kesimpulan bahwa perilaku konsumen dalam masyarakat digital akan dipengaruhi oleh peningkatan jumlah kemungkinan yang mengarah perilaku yang muncul dan tak terduga serta ada kecenderungan generasi mendatang berkeinginan memiliki akses tak terbatas ke konten internet tetapi disisi lain mereka enggan membayar[7]. Selain itu, tantangan utama dalam pemanfaatan Big Data antara lain eksplorasi Big Data merupakan proses yang kompleks, belum adanya tatakelola yang jelas dalam pemanfaatan Big Data, keterbatasan waktu, biaya, biaya yang mahal dan masih jarang piranti lunak yang dapat digunakan untuk menganalisa data dalam bahasa Indonesia serta SDM untuk pengembangan Big Data. Jadi tantangan yang ada saat ini lebih pada bagaimana perusahaan mengoptimalkan data yang dimiliki, untuk memberikan dampak yang positif.

\section{Big Data dan Perlindungan Privasi konsumen}

Tidak bisa kita pungkiri bahwa keberadaan big data memiliki peluang menjanjikan untuk merevolusi bisnis karena kemampuannya untuk mengautomasi berbagai hal dan bisa di akses secara real-time. Beberapa orang menyukai teknologi big data ini sebab mereka melihat potensi baik yang dapat diberikan kepada umat manusia, dan ekonomi digital. Namun, beberapa orang lainnya masih khawatir jika berbicara mengenai big data karena mereka juga melihat potensi membahayakan yang bisa dilakukan ketika perusahaan seakan memiliki akses tidak terbatas untuk mengawasi konsumen, bahkan dalam banyak hal, ini sudah mulai berjalan, Big data dapat digunakan untuk mengetahui perilaku konsumen lebih detail dibanding sebelumnya dan menerapkannya berdasarkan kebiasaan manusia. Bahkan beberapa riset yang telah dilakukan, banyak memanfaatkan data-data dari media sosial masyarakat Indonesia untuk memahami isu tertentu.

Mulai tahun 2017 big data akan terus memainkan peran penting .Karena teknologi terus berkembang dan dunia menjadi semakin terhubungkan, berbagai inovasi yang lebih besar akan muncul guna meningkatkan kualitas kehidupan dari hari ke hari mulai dari keamanan rumah, perawatan medis hingga kemudahan transportasi. Dengan demikian, pelanggaran keamanan juga akan semakin canggih dan juga tidak kalah pentingnya adalah masalah pelanggaran privasi akan menjadi pusat perhatian.

Konsep privasi menjadi semakin penting dibicarakan di era seperti sekarang, karena kemunculan teknologi yang mampu merekam dan menyimpan bentuk baru dari informasi pribadi, contohnya sidik jari, wajah dan bahkan retina mata seseorang. Proses merekam dan menyimpan tersebut tidak hanya dilakukan dalam skala kecil tapi juga skala besar. Privasi adalah konsep yang menjunjung tinggi kemandirian, otoritas, dan harga diri seseorang dengan menghargai keberadaan ruang pribadi (Unesco, 2012) 
Di era digital, informasi pribadi bukan hanya sebatas data seperti nomor telepon, alamat rumah, tanggal lahir, nama keluarga (orang tua atau ibu kandung), dan lainnya. Informasi pribadi juga bisa diambil dari: data transaksi keuangan online (kartu kredit) dan perbankan, kondisi kesehatan (seperti penggunaan aplikasi kesehatan), foto atau gambar yang diunggah online, lokasi (seperti media sosial Foursquare dll.) sangat mudah untuk di akses.

"Pernah ada kasus di Amerika Serikat yang mana seorang Ibu menggugat perusahaan ritel karena selalu mengirimkan kepada anaknya brosur produk-produk bayi. Tanpa disadari oleh sang Ibu, anaknya ternyata tengah hamil.

"Hal itu malah diketahui lebih dulu oleh ritel itu melalui analisis pola pembelian si anak di toko tersebut. Artinya, dengan memanfaatkan Big Data, ritel bisa menawarkan produk yang sesuai dengan kebutuhan pelanggan secara real time," (Fajar Muharandy)

Tidak hanya di dunia ritel, dibidang kesehatan sangat memungkinan terjadinya pelanggaran privasi. Kerahasiaan alat tes bisa semakin terancam Program tes inteligensi seperti tes Raven, Differential Aptitudes Test dapat diakses melalui compact disk. Implikasi dari permasalahan ini adalah, tes psikologi yang ada akan mudah sekali bocor, dan pengembangan tes psikologi harus berpacu dengan kecepatan pembocoran melalui internet tersebut. Penyalahgunaan pengetahuan bagi orang-orang tertentu untuk melakukan tindak kriminal. Kita tahu bahwa kemajuan di badang pendidikan juga mencetak generasi yang berpengetahuan tinggi tetapi mempunyai moral yang rendah. Contonya dengan ilmu komputer yang tinggi maka orang akan berusaha menerobos sistem perbankan dan lain-lain.

Di era digital, informasi adalah alat tukar yang ampuh untuk mengakses layanan-layanan online yang tersedia. Internet dirayakan sebagai simbol keterbukaan dan kebebasan. Pengguna bisa mengakses beragam pengetahuan dan layanan dengan gratis tanpa perlu membayar dengan uang. Mengapa para penyedia layanan dan konten online mau memberikan layanannya secara cuma-Cuma. (EBookModulKEMUDI.pdf).

Dengan semakin melonjaknya jumlah data di dunia maya, perlindungan privasi terhadap penggunanya pun semakin berkurang. Alasannya, karena semakin banyak data, semakin sulit pula melindungi privasi tiap-tiap penggunanya dari ancaman pihak luar. Faktor lain yang semakin memperkuat hal tersebut juga berasal dari tingkat public interest di dunia maya yang semakin tinggi. Ini yang akhirnya membuat privasi kian tak berharga.(Edmon Makarim). Tentu saja penggunaan big data yang tidak benar seperti ini akan merugikan konsumen, konsumen diletakkan pada tingkat posisi yang paling rendah dalam menghadapi perilaku para pengusaha. 


\section{Apa Yang Harus dilakukan}

Setiap harinya masyarakat Indonesia menghasilkan sejumlah data yang dapat dikelola untuk menghasilkan sebuah riset sosial mendalam yang berskala besar, serta memberikan dampak signifikan bagi sektor pembangunan. Bahkan sejak tahun 2000, statistik mencatat jumlah informasi yang disimpan pemerintah meningkat tajam dan, sejak 2013, diperkirakan akan terus bertumbuh menjadi dua kali lipat per tahun, bagaiman pada tahun 2018 tentu perkembangannya semakin masif. Oleh karena itu sudah saatnya pemerintah mengambil peran utama dalam upaya melindungi keamanan data dari masyarakatnya terutama terkait dengan privasi dan kebebasan berekspresi yang merupakan bagian penting dari hak konstitusi warga.

Adapun usulan yang diperlukan terkait dengan pengaturan perlindungan konsumen adalah sebagai berikut:

1. Menciptakan sistem perlindungan konsumen yang mengandung unsur keterbukaan akses dan informasi, serta menjamin kepastian hukum. Masyarakat juga diajarkan fungsi dan manfaat teknologi informasi dan perkembangannya yang semakin pesat harus selalu dikejar masyarakat agar masyarakat dapat mengikuti.

2. Memberikan perlindungan kepada konsumen dari paraktik usaha yang menipu dan menyesatkan.

3. Memadukan penyelenggaraan, pengembangan dan pengaturan perlindungan konsumen dengan bidang-bidang perlindungan pada bidang-bidang lain ; Bait and Switch adv, Mock-up-adv dll.

4. Masyarakat diberikan pemahaman menyeluruh tentang etika dalam teknologi informasi agar dapat membentengi diri dalam penyalahgunaan privasi, baik itu dari orang lain maupun negara. Dengan demikian data-data yang tersalurkan adalah data yang memang dibutuhkan untuk pengembangan negara dan bukan data pribadi yang tidak berhak untuk disebarkan.

Sehubungan dengan itu di berbagai negara, khususnya di negara-negara maju dan di dunia internasional telah dilakukan pembaharuan-pembaharuan hukum yang berkaitan dengan tanggungjawab produsen ( product liability), terutama dalam rangka mempermudah pemberian konpensasi bagi konsumen yang menderita kerugian akibat produk yang diedarkan di masyarakat. Secara khusus yang dimaksud dengan product liability adalah tanggungjawab secara hukum dari orang atau badan hukum yang menghasilkan suatu produk, dan/atau pihak yang menjual produk tersebut dan/atau pihak yang mendistribusikan produk tersebut, termasuk juga disini pihak yang terlibat dalam rangkaian komersial tentang persiapan atau penyebaran dari suatu produk, dan juga termasuk para pengusaha bengkel, pergudangan, para agen dan pekerja dari badanbadan usaha di atas. Bahwa upaya-upaya perlindungan konsumen adalah lebih dimaksudkan untuk meningkatkan martabat dan kesadaran konsumen dan/atau sekaligus dimaksudkan dapat mendorong pelaku usaha di dalam menyelenggarakan kegiatan usahanya dilakukan dengan penuh rasa tanggungjawab. Sudah barang tentu keperluan adanya hukum untuk memberikan perlindungan konsumen Indonesia merupakan suatu hal yang tidak bisa dihindarkan, sejalan dengan tujuan pembangunan nasional kita, yaitu pembangunan manusia Indonesia yang seutuhnya.(M.Sofyan Lubis). 


\section{CONCLUSIONS}

Big Data adalah suatu trend yang mencakup area yang luas dalam dunia bisnis dan teknologi. Big Data menunjuk pada teknologi dan inisiatif yang melibatkan data yang begitu beragam, cepat berubah, atau berukuran super besar sehingga terlalu sulit bagi teknologi, keahlian, maupun infrastruktur konvensional untuk dapat menanganinya secara efektif.

Pemanfaatan Big Data di Indonesia sudah mulai tumbuh baik di sektor bisnis maupun di sektor publik. Tantangan yang ada saat ini lebih pada bagaimana perusahaan mengoptimalkan data yang dimiliki, untuk memberikan dampak yang positif. Dengan semakin melonjaknya jumlah data di dunia maya, perlindungan privasi terhadap penggunanya pun semakin berkurang. Oleh karena itu perlu upaya dari pemerintah untuk memberikan kepastian hukum dan perlunya masyarakat diberikan pemahaman menyeluruh tentang etika dalam teknologi informasi agar dapat membentengi diri dalam penyalahgunaan privasi.

\section{REFERENCES}

Vience Mutiara Rumata, “Peluang dan Tantangan Big Data dalam Penelitian Ilmu Sosial: sebuah Kajian Literatur”, Jurnal Penelitian Komunikasi dan Opini Publik, Vol 20, No 1. Agustus 2016.

Hapnes Toba,’Big Data: Menuju Evaluasi Era Informasi Selanjutnya”, Conference paper, April 2015, (www. Researchgate.net/publication/2747126686)

Aleksandra Krajnovic , "Digital Marketing and behavioral Economics", Conference paper, October 2016, http//www.reseachgate.net/publication/309490126.

Emyana Ruth Eritha S, “Implementasi Teknologi Big Data di Lembaga Pemerintahan Indonesia”, Jurnal Penelitian Pos dan Informatika,JPPI Vol 6 No. 2, 2016.

Sue Yasav," The Impact of Digital Technology on Consumer Purchase Behavior", the journal of Financial Perspectives:Fintech, Vol 3- issue 3, 2015.

John F.Quigley,"Consumer Behavior in Digital Markets", Research paper, southern illinois University Carbondale, OpenSIUC,2015.

Veikko Halttunsen,"Consumer Behavior in Digital Era", Academic dissertation, the Faculty of Information Technology of the University of Jyaskyla,2016.

Referensi Tambahan:

www.apaitubigdata.com diakses tgl 2/5/2018

http://medium.com/skyshidigital/Berkenalan.dengan Big data-a5fd941122f8

http://kemudi.xye/static/web/Modul/\%5Blores\%5D20modul\%20\%20EBookModulKEMUDI.pdf 